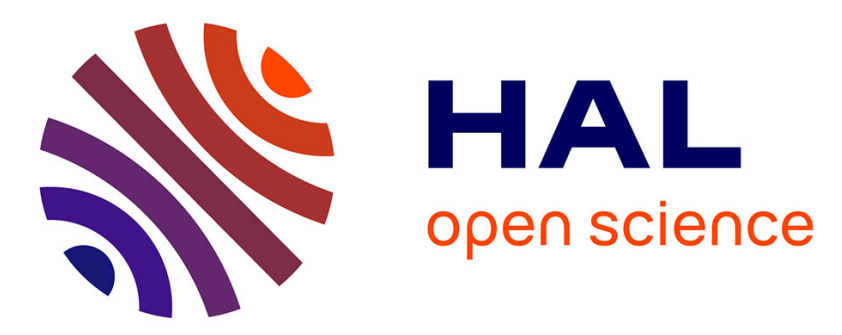

\title{
Synergistic feedbacks from ocean and vegetation on the African monsoon response to mid-Holocene insolation
}

\author{
P Braconnot, S Joussaume, O Marti, N de Noblet
}

\section{To cite this version:}

P Braconnot, S Joussaume, O Marti, N de Noblet. Synergistic feedbacks from ocean and vegetation on the African monsoon response to mid-Holocene insolation. Geophysical Research Letters, 1999, 26, pp.2481-2484. 10.1029/1999GL006047 . hal-03022867

\section{HAL Id: hal-03022867 https://hal.science/hal-03022867}

Submitted on 25 Nov 2020

HAL is a multi-disciplinary open access archive for the deposit and dissemination of scientific research documents, whether they are published or not. The documents may come from teaching and research institutions in France or abroad, or from public or private research centers.
L'archive ouverte pluridisciplinaire HAL, est destinée au dépôt et à la diffusion de documents scientifiques de niveau recherche, publiés ou non, émanant des établissements d'enseignement et de recherche français ou étrangers, des laboratoires publics ou privés. 


\title{
Synergistic feedbacks from ocean and vegetation on the African monsoon response to mid-Holocene insolation
}

\author{
P. Braconnot, S. Joussaume, O. Marti, and N. de Noblet \\ Laboratoire des Sciences du Climat et de l'Environnement, Gif-sur-Yvette, France.
}

\begin{abstract}
We used a coupled ocean-atmosphere General Circulation Model without flux corrections, iteratively coupled to a biome model, to explore the impact of vegetation and ocean feedbacks on mid-Holocene monsoon change in northern Africa. We show that both feedbacks significantly increase the northward penetration and the intensity of the monsoon rainfall. The major contribution of the ocean is to enhance the inland moisture advection, whereas that of vegetation is to increase local recycling. Synergistic interactions between ocean and vegetation feedbacks play a critical role in the African monsoon changes, yielding to model results in much better agreement with observations.
\end{abstract}

\section{Introduction}

Sub-Saharan West Africa is very sensitive to monsoon rain variability [Druyan, 1989]. Several studies relate the variability in the intensity of the rainy seasons in this region to sea surface temperature anomalies [e.g. Folland et al., 1986; Semazzi et al., 1996]. Others invoke continental factors such as surface albedo and vegetation cover [ e.g. Charney, 1975; Xue and Shukla, 1993]. Much wetter conditions prevailed in this region 6000 years ago [e.g. Jolly et al., 1998; StreetPerrott and Perrott, 1993]. They are attributed to an enhancement of the monsoon activity caused by changes in Earth's orbital parameters. However with the orbital forcing alone, atmospheric general circulation models (GCM) underestimate the moisture increase north of $18^{\circ} \mathrm{N}$ [Joussaume et al., 1999], suggesting that ocean and land surface feedback need also to be considered.

Recent simulations in which vegetation changes were prescribed to the atmospheric model [Street Perrott et al., 1990; Kutzbach et al., 1996], or computed using coupled atmosphere-biome models [Claussen and Gayler, 1997; Texier et al., 1997] showed that vegetation contributes to enhance the orbitally-induced monsoon change. More recently, coupled ocean-atmosphere simulations also highlighted the positive feedback of the ocean [Hewitt and Mitchell, 1998; Kutzbach and Liu, 1997]. However, even if some results are consistent with paleodata in many places, the full reconstruction of past vegetation [Jolly et al., 1998] and lake level status [StreetPerrott and Perrott, 1993] across northern Africa has not been simulated yet. Only one simulation with a model of intermediate complexity included interactions between ocean, atmosphere and terrestrial vegetation [Ganopolski et al., 1998]. Vegetation extended at the expense of desert areas, but the ocean only accounts for a small part to these changes. The

Copyright 1999 by the American Geophysical Union.

Paper number 1999 GL006047.

0094-8276/99/1999GL006047\$05.00 ocean model though does not resolve the full ocean equatorial dynamics, and the rather coarse resolution prevents the simulation of detailed regional monsoon changes. We propose to use a more comprehensive model to adress the possibility of synergistic interaction between vegetation and ocean feedbacks in the tropics with a focus on the climate of northern Africa.

\section{Experimental design}

We used the IPSL (Institut Pierre Simon Laplace, Paris) global coupled ocean-atmosphere GCM [Braconnot et al., 1997; Braconnot et al., in press], iteratively coupled to the BIOME1 vegetation model [Prentice et al., 1992]. The atmospheric model has 64 points in longitude, 50 points regularly spaced in sine of the latitude and 11 sigma levels, and includes the land-surface scheme SECHIBA [Ducoudré et al., 1993]. The oceanic model has 92 points in longitude, 76 points in latitudes and 31 vertical levels. The two models exchange once a day surface temperature, sea-ice cover, momentum, heat and fresh water fluxes, including river runoff. None of these fluxes are corrected and the simulations are stable. The modern-day mean seasonal cycle is reasonably well represented, despite a $2{ }^{\circ} \mathrm{C}$ cold bias in tropical sea surface temperatures (SST) and a $2^{\circ}$ too far north location of the summer monsoon rainfall peak in Africa [Braconnot et al., smi]. To compute vegetation changes, the biome model is forced with the mean climate change simulated by the coupled ocean-atmosphere model (Figure. 1).

We did four simulations with this model: a 150-year simulation for the present day climate (OAOk), a 150-year simulation for the mid-Holocene climate (OA6k) with Earth's orbital parameters prescribed as in the Paleoclimate Modeling Intercomparison Project [Berger, 1978; Joussaume and Taylor, 1995], and two 50-year simulations for the midHolocene climate (OAV6k and $\mathrm{OAV}_{1} 6 \mathrm{k}$ ) for which we also prescribed as boundary conditions the biome distributions reconstructed respectively from OA6k and OAV6k (Figure 1). In all simulations the $\mathrm{CO}_{2}$ level was kept to its present value (345 ppm). The length of our simulations is sufficient to study changes in the seasonal cycle, which mainly affect the upper ocean, but not to bring the deep ocean to equilibrium. However, the oceanic drift of $0.2^{\circ} \mathrm{C} /$ century at the ocean surface and of $0.04^{\circ} \mathrm{C} /$ century at depth is similar in all simulations and negligible compared to the imposed perturbation. Our analysis and biome reconstructions are based on 20-year mean annual cycles, using years 80 to 100 for OA0k and OA6k and the last twenty years for OAV6k and OAV $16 \mathrm{k}$.

\section{Ocean and vegetation feedbacks on monsoon changes}

The 6000 years BP Earth's orbital parameters increase the amplitude of the seasonal cycle of solar radiation in the north- 


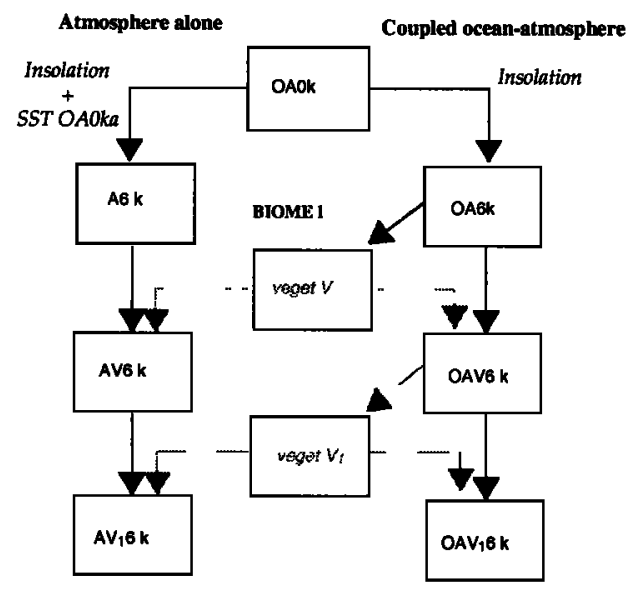

Figure 1. Schematic diagram of the experimental design. For the two iterations with the biome model, the vegetation was reconstructed respectively from OA6k and OAV6k departures to OAOK and then prescribed as boundary condition over land both in the coupled model and the atmosphere alone model.

em hemisphere. As a result, insolation in June-July-AugustSeptember was about 5\% larger than it is today. The continental thermal low deepened over the warmer land, which favoured the inland penetration of moisture from the ocean, thereby increasing the monsoon rain intensity. In OA6k, the Sahara is 1.5 to $2^{\circ} \mathrm{C}$ warmer than today and rainfall is increased up to 5 $\mathrm{mm} / \mathrm{d}$ in a few places (Figure 2). In the Atlantic, the simulated sea surface temperatures (SST) are warmer to the north of $15^{\circ} \mathrm{N}$ and colder to the south. This dipole resembles the oceanic anomalies involved in modern Sahel droughts [Folland et al., 1986]. It favours late summer precipitation to the north of the present day position of the rainbelt [Braconnot et al., in press; Hewitt and Mitchell, 1998]. Over land, the simulated surface cooling results from a larger cloud cover, which reflects back to space solar radiation, and from larger evapotranspiration. When vegetation is made interactive, all these patterns are reinforced. The warming is larger than $3^{\circ} \mathrm{C}$ in north-west Africa and the precipitation increase exceeds 5 $\mathrm{mm} /$ day across a broad region (Figure 2).

The largest change in precipitation is found over land between $20^{\circ} \mathrm{W}-30^{\circ} \mathrm{E}$ and $12^{\circ} \mathrm{N}-23^{\circ} \mathrm{N}$. Compared to OAOk, it represents an increase of $37 \%$ in OA6k and of $69 \%$ in OAV $\mathrm{OAk}_{1} 6 \mathrm{k}$. Rainfall (P) in this region receives most of its moisture from the low-level south-west monsoon flow off the tropical Atlantic. Local evaporation (E) also helps maintain monsoon activity by providing a local source of moisture. Since we consider only monthly averages, P-E can be used to represent the amount of precipitation $(P)$ resulting from moisture advection. Total rainfall is the sum of these two contributions (Figure 3). At present (OAOk), P-E is larger than E only during July and August (Figure 3). In OA6k, the change in P-E accounts for most of the change in precipitation. Moisture advection dominates local recycling from June to September, period during which precipitation is larger than $2 \mathrm{~mm} /$ day. When vegetation interacts $\left(\mathrm{OAV}_{1} 6 \mathrm{k}\right)$, the local recycling provides most of the additional precipitation change, because plants are more efficient than a bare soil at extracting soil water for evapotranspiration (Texier at al., in press). Note also that advection is larger in May. The dominant biomes in the region are no more Desert and Steppe but Savanna. The surface albedo is then reduced by $6 \%$, which favours the surface warming in spring and triggers the monsoon onset by increasing the land-sea contrast (Figure 3 ). These results confirm that the land surface conditions have a large impact on monsoon changes. They also show that when both ocean and vegetation feedbacks are included the rainy season lengthens leading
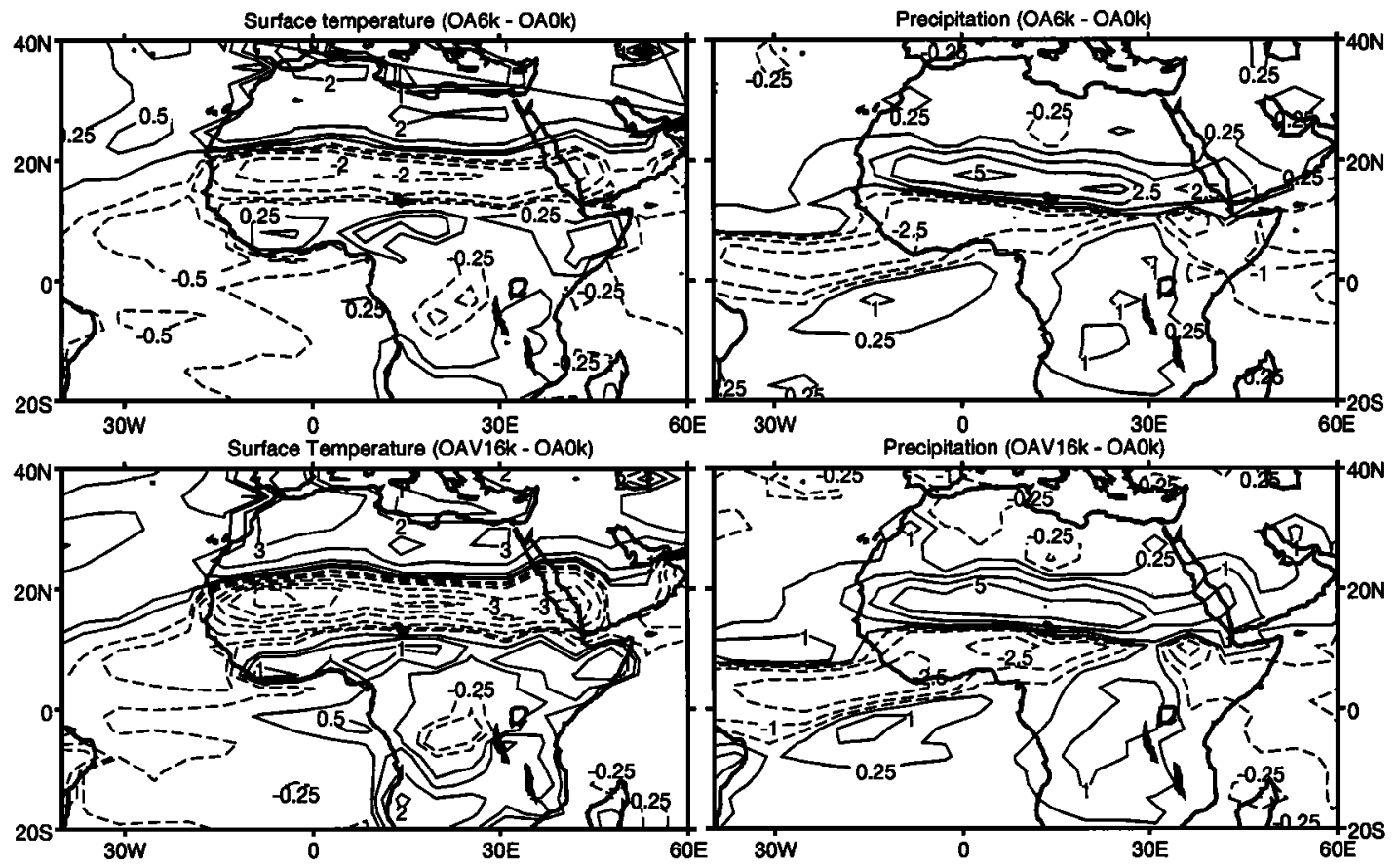

Figure 2. $6000 \mathrm{BP}$ change in June-July-August-September surface temperature (left) and precipitation (right) over Africa as simulated with the coupled ocean-atmosphere model (top) and with the coupled ocean-atmosphere-vegetation model (bottom). Isolines are $+/ 0.25,0.5,1,2,3$, and 4 Celsius for temperature and $+/-0.25,1,2.5$ and $5 \mathrm{~mm} /$ day for precipitation. 


\section{Africa (20W-30E 12N-23N) land for the coupled model}

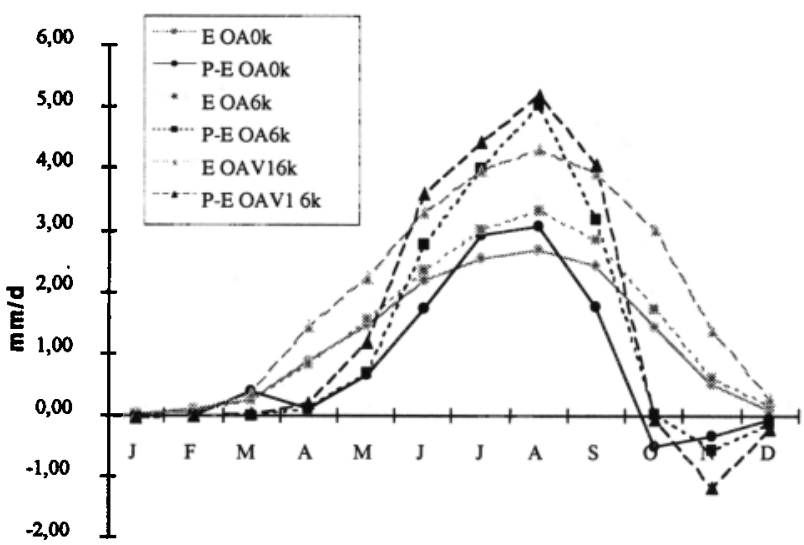

Figure 3. Evaporation (E) and precipitation minus evaporation (P-E) averaged over Africa from $20^{\circ} \mathrm{W}$ to $30^{\circ} \mathrm{E}$ and $12^{\circ} \mathrm{N}$ to $23^{\circ} \mathrm{N}$ and plotted as a function of months for the coupled simulations of modern climate (OA0k), of $6000 \mathrm{BP}$ climate with no change in vegetation (AO6k), and for the last iteration at 6 $000 \mathrm{BP}$ with the biome model (OAV1 6k). Total precipitation is the sum of $E$ and $P-E$. Values are in $\mathrm{mm} /$ day.

to larger than $2 \mathrm{~mm} /$ day precipitation rates from May to October.

\section{Synergism between ocean and vegetation feedbacks}

To better infer the role of the interactive ocean in the monsoon response we ran three additional 20-year simulations with the atmospheric model alone (Figure 1). In A6k we only changed insolation as in OA6k. In AV6k and $A V_{1} 6 k$, we respectively prescribed the same vegetation as in OAV6k and $\mathrm{OAV}_{1}$ 6k (Figure 1). To avoid any bias that could arise from differences between modern climatology and SST simulated by the coupled model, we prescribed as surface boundary condition in all these simulations the daily SSTs simulated by OA0k from years 80 to 100 . With this methodology, OA0k is the reference for all 6000 years BP simulations. Contrarily to standard atmosphere-biome coupled experiments we intentionally did not prescribe to $\mathrm{AV}$ and $\mathrm{AV}$, the vegetation respectively reconstructed from $A$ and $A V$, because we wanted to see how important is the role of the ocean in further shifting the monsoon rainfall to the north for a given biome distribution. However, even if we did not use them to force the atmospheric model, we reconstructed these biome distributions in order to compare the two sets of experiments (Figure 4).

Four biome types are found in western north Africa $\left(20^{\circ} \mathrm{W}\right.$ to $30^{\circ} \mathrm{W} ; 5^{\circ} \mathrm{N}$ to $30^{\circ} \mathrm{N}$ ) with varying proportions across the simulations. Figure 4 shows that at each iteration with the biome model, the reduction of desert area is larger for the simulation which includes ocean feedback (OA6k versus $A 6 k$, $O A V 6 k$ versus $A V 6 k$ and $O A V_{1} 6 k$ versus $\left.A V_{1} 6 k\right)$. The largest reduction of desert ( $15 \%$ compared to present) is produced by $\mathrm{OAV}_{1} 6 \mathrm{k}$, resulting in a $5^{\circ}$ northward shift of the desert/steppe boundary (Figure $4 \mathrm{~b}$ ). Warm grass shrub is also reduced. The two biome types are replaced by more moisture-demanding plants: xerophytic wood/scrub and tropical dry forest/savanna. Since vegetation is the same in coupled and atmosphere-alone simulations, the recycling efficiency is also quite similar. Indeed, between $12^{\circ} \mathrm{N}$ and $23^{\circ} \mathrm{N}$, the evaporation increases by $17 \%$ in OA6k versus $11 \%$ in $\mathrm{A} 6 \mathrm{k}$, and by $57 \%$ in $\mathrm{OAV}_{1} 6 \mathrm{k}$ versus $50 \%$ in $\mathrm{AV}_{1} 6 \mathrm{k}$ compared to $\mathrm{OAOk}$. On the other hand, the moisture advection increases by $57 \%$ for $O A$ $6 \mathrm{k}$ versus $39 \%$ for $A 6 \mathrm{k}$, and by $81 \%$ in $O A V_{1} 6 \mathrm{k}$ versus $60 \%$ in $A V_{1} 6 \mathrm{k}$, which stresses that the ocean response has a large impact on the advection.

The vegetation change we prescribed to both $O A V_{1} 6 k$ and $A V_{1} 6 \mathrm{k}$ resulted from the change in precipitation produced in OAV6k. The interesting point is that the atmosphere-vegetation alone system in $A V_{1} 6 \mathrm{k}$ is not able to sustain the amount of precipitation simulated in OAV6k (Figure 4). This implies that the equilibrium atmosphere-vegetation system would have stabilized to a vegetation extent which is between the one simulated by AV6k and $A V_{1} 6 k$. The biome distribution we prescribed to the atmospheric model is thus overestimated

\section{biome distribution $\left(20^{\circ} \mathrm{W}-30^{\circ} \mathrm{E} 5^{\circ} \mathrm{N}-30^{\circ} \mathrm{N}\right)$}

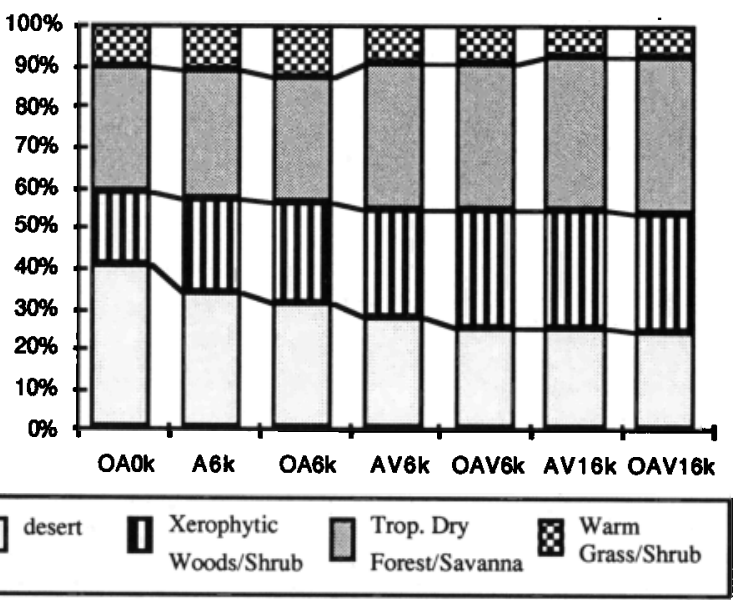

Annual mean precipitation zonally averaged from $20^{\circ} \mathrm{W}$ to $30^{\circ} \mathrm{E}$ over land

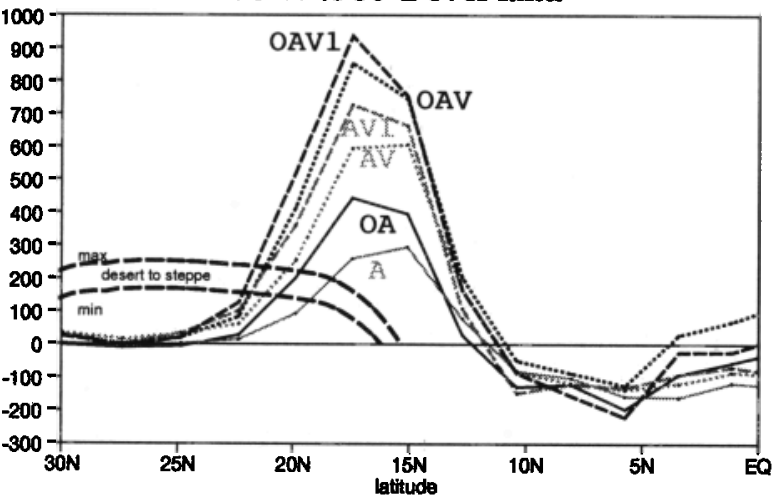

Figure 4. Biome distribution over West Africa in a region extending from $20^{\circ} \mathrm{W}$ to $30^{\circ} \mathrm{E}$ and $5^{\circ} \mathrm{N}$ to $30^{\circ} \mathrm{N}$ (top). Annual mean precipitation change at $6000 \mathrm{BP}$ (in mm/year) zonally averaged over North Africa from $20^{\circ} \mathrm{W}$ to $30^{\circ} \mathrm{E}$ over land (bottom) for the coupled and atmosphere-alone simulations in response to $6000 \mathrm{BP}$ changes in insolation (respectively OA and $\mathrm{A}$ ) and in response to the $6000 \mathrm{BP}$ change in insolation and vegetation for the two iterations with the biome model (respectively OAV and OAV1 for the coupled simulations and $A 1$ and $A V 1$ for the atmosphere-alone simulations). The hatched lines represent the additional precipitation required to support grassland compared to modern biome distribution [Joussaume et al., 1999]. 
compared to the one we would have precribed in an equilibrium atmosphere-biome model. On the other hand, precipitation still increases whith a slight northward shift in $\mathrm{OAV}_{1} 6 \mathrm{k}$, which clearly demonstrates that synergistic interactions occur between vegetation and ocean feedbacks.

Additional iterations with the biome model are required to reach full equilibrium of coupled ocean-atmosphere system. We stopped after 2 iterations to save computer time because the changes between OAV6k and $O A V_{1} 6 \mathrm{k}$ were small compared to those we obtained between OA6k and OAV6k. We also know from other coupled atmosphere-biome experiments [Texier et al., 1997), Claussen and Gayler, 1997)] that additional iterations are not likely to change our results.

\section{Conclusion}

Our study clearly demonstrates that interactive ocean and vegetation are both needed to reproduce the wetter climatic conditions prevailing in northern Africa during the midHolocene, as indicated by proxy data [Jolly et al., 1998] However, we still do not simulate enough additional precipitation in the vicinity of $23^{\circ} \mathrm{N}$. Part of this may be model dependent, because our atmospheric model is known to produce a too large subsidence in Sahara (De Noblet et al., smi). Moreover, the vegetation model was asynchronously coupled because it is a static model. We hope that in near future these results will be improved with synchronously coupled oceanatmosphere-dynamical vegetation models. In any case, these results point to the importance of introducing vegetation feedbacks in future climate change scenarios, which have up to now only be based on coupled ocean-atmosphere models.

Acknowledgements. We use version IPSL-CM1 of the coupled model. This version benefits from discussions and interactive work with the LMD, the LODYC and the CERFACS. Computer time was provided by Commissariat à l' Energie Atomique. This work was supported by PNEDC and by EEC contract (ENV4-CT95-0075). LSCE $n^{\circ} 0288 \mathrm{~A}$

\section{References.}

Berger, A., Long-term variation of daily insolation and Quaternary climatic changes, J. of Atmos. Sci., 35, 2362-2367, 1978.

Braconnot, P., O. Marti, and S. Joussaume, Adjustment and feedbacks in a global coupled ocean-atmosphere model, Climate Dyn., 13, 507$519,1997$.

Braconnot, P., O. Marti, S. Joussaume, and Y. Leclainche, Ocean feedback in response to $6 \mathrm{kyr}$ BP insolation, J. of Climate, accepted.

Charney, Dynamics of deserts and droughts in the Sahel, Quart. J. Roy. Met. Soc., 101, 193-202, 1975.

Claussen, M., and V. Gayler, The greening of the Sahara during the mid-Holocene: results of an interactive atmosphere-biome model, Global Ecol. and Biogeogr. Lett. 6, 369-377, 1997.

Druyan, L.M., Advances in the study of Sub-Sahara droughts, Int. J. Climatol., 9, 77-90, 1989.

Ducoudré, N., K. Laval, and A. Perrier, SECHIBA, a New Set of Parameterizations of the Hydrologic Exchanges at the Land-
Atmosphere Interface within the LMD Atmospheric General Circulation Model, J. Clim., 6, 248-273, 1993.

Folland, C.K., T.N. Palmer, and D.E. Parker, Sahel rainfall and world wide sea surface temperature, Nature, 320, 602-607, 1986.

Ganopolski, A., C. Kubatzki, M. Claussen, V. Brovkin, and V. Petoukhov, The influence of Vegetation-atmosphere-Ocean Interaction on Climate During the Mid-Holocene, Science, 280, 1916-1919, 1998.

Hewitt, C.D., and J.F.B. Mitchell, A fully coupled GCM simulation of the climate of the mid-Holocene, Geophys. Res. Let., 25, 361-364, 1998.

Jolly, D., and 32 co-authors, Biome reconstruction from pollen and plant macrofossil data for Africa and the Arabian peninsula at $\mathbf{0}$ and $6 \mathrm{ka}$., Journal of Biogeography, 1998.

Joussaume, S., and K.E. Taylor, Status of the Paleoclimate Modeling Intercomparison Project, in Proceedings of the first international AMIP scientific conference, WCRP-92, Monterey, USA, 425-430, 1995.

Joussaume, S., and 33 co-authors, Monsoon changes for 6000 years ago: results of 18 simulations from the Paleoclimate Modeling Intercomparison Project (PMIP)., Geophys. Res. Lett., 26, 859-862, 1999.

Kutzbach, J., G. Bonan, J. Foley, and S.P. Harrison, Vegetation and soil feedbacks on the response of the African monsoon to orbital forcing in the early to middle Holocene, Nature, 384, 623-626, 1996.

Kutzbach, J.E., and Z. Liu, Response of the African Monsoon to Orbital Forcing and Ocean Feedbacks in the Middle Holocene, Science, 278, 440-443, 1997.

Prentice, I.C., W. Cramer, S.P. Harrisson, R. Leemans, R.A. Monserud, and A.M. Salomon, A Global Biome Model based on Plant Physiology and Dominance, Soil Properties and Climate., Journal of Biogeography, 19, 117-134, 1992.

Semazzi, F.M., B. Burns, N. Lin, and J. Schemm, A GCM study of the teleconnection between the continental climate of Africa and global sea surface temperature anomalies, J. Clim., 9, 2480-2497, 1996.

Street Perrott, F.A., J.F.B. Mitchell, D.S. Marchand, and J.S. Brunner, Milankovitch and albedo forcing of the tropical monsoons: a comparison of geological evidence and numerical simulations for 9000 yr BP, Transactions of the Royal Society of Edinburgh, 81, 407, 1990.

Street-Perrott, F.A., and R.A. Perrott, Holocene vegetation, lake levels and climate of Africa, in Global Climates since the Last Glacial Maximum, edited by H.E. Jr Wright et al., pp. 318-356, University of Minnesota Press, Minneapolis, 1993.

Texier, D., N. de Noblet, and P. Braconnot, 1999: Sensitivity of the African and Asian monsoons to mid-Holocene insolation and data inferred surface changes, $J$. of Climate, in press

Texier, D., N. de Noblet, S.P. Harrison, A. Haxeltine, S. Joussaume, D. Jolly, F. Laarif, I.C. Prentice, and P. Tarasov, Quantifying the role of biosphere-atmosphere feedbacks in climate change: a coupled model simulation for $6000 \mathrm{yr}$ BP and comparison with paleodata for northern Eurasia and northern Africa, Climate Dyn., 13, 865-882, 1997.

Xue, Y., and J. Shukla, The influence of land surface properties on Sahel climate. Part I : desertification, J. Clim., 6, 2232-2245, 1993.

P. Braconnot, S. Joussaume, O. Marti, and N. de Noblet, Laboratoire des Sciences du Climat et de 1' Environnement, UMR CEA-CNRS 1572, CEA Saclay bat 709, 91191 Gif sur Yvette cedex, France (email: pasb@lsce.saclay.cea.fr; syljous@lsce.saclay.cea.fr;

marti@lsce.saclay.cea.fr; noblet@lsce.saclay.cea.fr)

(Received March 30, 1999; revised June 9, 1999; accepted June 29, 1999.) 